\title{
Radon Exhalation from Five Wood Species ${ }^{1}$
}

\author{
Ju Yong $\mathrm{Lee}^{2} \cdot$ Gyu Woong $\mathrm{Choi}^{3} \cdot$ Seog Goo Kang $\mathbb{D}^{3, \dagger}$
}

\begin{abstract}
Radon radiation exposures in home have been posed as a potential cancer hazard. This research aims to present the basic data of the indoor radon concentration level by examining the radon exhalation rates of wood species. Radon exhalation rates from five commonly used wood species in Korean wood building construction were measured with Continuous Radon Monitor (CRM), Model 1028 (Sun Nuclear Co., USA) using the Closed Chamber Method (CCM). The mass exhalation rate was observed to vary from $0.00089 \mathrm{~Bq} \cdot \mathrm{kg}^{-1} \cdot \mathrm{h}^{-1}$ to $0.00181 \mathrm{~Bq} \cdot \mathrm{kg}^{-1} \cdot \mathrm{h}^{-1}$, whereas the surface exhalation rate was observed to be $0.00677-0.01517 \mathrm{~Bq} \cdot \mathrm{m}^{-2} \cdot \mathrm{h}^{-1}$. The radon exhalation rate of Quercus accutissima Carruth (white oak) which has the highest density showed the highest figure among the five wood species, on the other hand, the rest of four species showed similar results which were similar to the radon exhalation rates of wood in the U.S.A. and Canada. The average of the concentration measured by the CCM represented well up to the second half-life period (7.7 days). Because result of these small quantities seems to indicate that radon exhalation from the tested wood species has almost negligible impact, the main culprit of the high indoor radon concentration is clearly derived from the background of surrounding wood house. Therefore, as a safety precaution, infrastructures made of wood materials should be designed with the consideration of influx of radon and built accordingly. Furthermore, it is highly desirable that wood will be needed to use for furniture and interior finishing material in indoor environment.
\end{abstract}

Keywords: indoor radon, building materials, closed chamber method, wood species, exhalation rate

\section{INTRODUCTION}

The recent studies of people exposed to radon have confirmed that radon in an indoor environment represents a serious health hazard. Depending on the radon concentration and the length of exposure (Webb, 1992; Lubin and Boice, 1997; Neuberger and Gesell, 2002; Lazar et al., 2003; Jang et al., 2017), long-term and elevated exposure to radon poses increased risk of developing lung cancer resulted in many studies.
The chance to have lung cancer elevates by $16 \%$ per $100 \mathrm{~Bq} / \mathrm{m}^{3}$ (95\% confidence interval (CI) 5-31\%). The relation of dose-response is proportional - for example, the risk of lung cancer grows proportionally with expanding radon exposure (WHO, 2009). While health effects of radon have emerged in many countries, the international commission for Radiological protection (ICRP) has also emphasized on a radon alert that areas, where more than $1 \%$ of buildings have indoor radon concentration higher than the 10 times of national

\footnotetext{
${ }^{1}$ Date Received July 28, 2018, Date Accepted November 12, 2018

2 Department of Civil and Environmental Engineering, College of Engineering, KAIST, Daejeon 34141, Republic of Korea

${ }^{3}$ Department of Bio-based Materials, College of Agriculture \& Life Science, Chungnam National University, Daejeon 34134, Republic of Korea

† Corresponding author: Seog Goo Kang (e-mail: lachesis@cnu.ac.kr, ORCID: 0000-0002-2440-7070)
} 
average, should be considered as radon prone areas to prevent high prolonged exposures.

${ }^{222} \mathrm{Rn}$ is a naturally occurring colorless, odorless, tasteless, and radioactive noble gas, which is formed by the immediate decay of ${ }^{226} \mathrm{Ra}$. It arises spontaneously as an intermediate step in the normal radioactive decay chains via which ${ }^{238} \mathrm{U}$ in the earth crust slowly decays into lead. The half-life of ${ }^{222} \mathrm{Rn}$ (only 3.82 days) is long enough to concentrate for part of it to diffuse from the radon sources to the indoor air. Therefore, ${ }^{222} \mathrm{Rn}$ is the most dominant hazardous radionuclide among the radon isotopes in interior daily life.

It is estimated that people are spending more than $80 \%$ of their time in indoors. Therefore, the quality of air indoors is quickly becoming a major concern for many. According to the European Lung white book, indoor air quality is greatly influenced by four main sources: penetrating outdoor air; specific indoor pollution sources; interactions between building system/ construction techniques; and occupants (Gibson et al., 2013). Radon gas permeates through walls into dwellings from different outdoor sources: soil, air, and surrounding buildings, and even indoor sources: building materials, water supplies, and gas lines. (Jing et al., 2010). Therefore, ways of preventing the influx of pollutants from the outside sources, and selecting building materials, especially the interior finishing materials, should be carefully considered to decrease potential radon exposures. For example, radionuclides $\left({ }^{222} \mathrm{Rn}\right)$ and its decay products, may reach alarming levels of concentration in infrastructures that lack adequate ventilation. Indoor pollutants may have a momentous biological impact even at low concentrations over long exposure periods. (Gibson et al., 2013). Although many researchers tried to suggest counterplans on these situations, radon gas elimination on the proper practical side is not developed yet. For example, there were efforts undergoing to reduce the radon concentration by using the charcoal board, activated charcoal board (Cho et al., 2011), and carbonized boards (Lee et al., 2014) for the building materials in Korea. Radon concentration levels should be a concern in dwellings as it poses health risks that can lead to cancer. Accordingly, taking measures to protect against radon exposure should not be ignored. Reducing radon emission at its source by carefully choosing construction materials, or installing ventilation systems that can filter radon emissions should be considered in architectural planning and design.

Korea Institute of Nuclear Safety, has conducted a test to inspect radon concentration levels in various indoor environments. In structures built from ochre materials, radon concentration levels were $74.1 \mathrm{~Bq} \cdot \mathrm{m}^{-3}$; in structures built from wooden materials, concentration levels were $54.9 \mathrm{~Bq} \cdot \mathrm{m}^{-3}$; in structures built from concrete materials, concentration levels were $53.1 \mathrm{~Bq} \cdot \mathrm{m}^{-3}$; and in prefabricated structures, the concentration levels were 36.6 $\mathrm{Bq} \cdot \mathrm{m}^{-3}$ (Korea Institute of Nuclear Safety, 2002). More specifically, out of the radon concentration levels mentioned above, radon emission from structural materials contributed $37 \mathrm{~Bq} \cdot \mathrm{m}^{-3}$ from wooden materials, $26.8 \mathrm{~Bq} \cdot \mathrm{m}^{-3}$ from concrete, $25.9 \mathrm{~Bq} \cdot \mathrm{m}^{-3}$ from cement blocks, and $22.2 \mathrm{~Bq} \cdot \mathrm{m}^{-3}$ from tiling (National Institute of Environmental Research, 2010). The research mentioned above resulted in wooden structures having the highest radon concentration levels among the surveyed buildings of different material types. However, the research did not provide much detailed information on the architectural design and the species of wood used to construct the tested wooden structure, and the focus of the research was not on the correlation of radon exhalations and wood (Lee et al., 2015; Chen, 2010; Jang, 2004; Najam et al., 2013; Lee et al., 2007). High indoor radon concentration of wood structures built from wooden materials does not mean high emanation rates from wood itself. Nevertheless, it is been reported that the measurement of radon levels in Korean domestic wood house possesses high radon 
concentration, but it was miscalculated and concluded with misinformation concerning wood having a direct influence on the radon concentration level. It is necessary to avoid this urgent misunderstanding.

The existence of radon in indoor air was verified as early as 1950. Beginning of radon research was introduced origins of indoor radon, decisive factors of concentration, health effects, and alleviation approaches from 1970s to early 1980s. Meanwhile, a worker with radioactivity contamination was found during routine monitoring by a nuclear power plant in Pennsylvania. The source of the problem resides in the fact of a high radon concentration in his home. In 1984, the widely publicized incident in the United States triggered a public interest about the problem of indoor radon that made intensified investigations. Ingersoll (1983) and Zikovsky (1992) reported that the mean radon emanation rates of unknown wood species were the lowest of 0.02 $\mathrm{pCi} \cdot \mathrm{kg}^{-1} \cdot \mathrm{h}^{-1}$ in many building materials. Since then, the studies about the rates of wood have not yet been investigated to date although many radon studies discovered about the radon emanation on building materials. Besides, there are such a difficulty to search papers that studied radon emanation from wood.

National Research Council (US) Committee (1999) explained that Radium, chemically similar to calcium, is imbibed from the soil by plants. The radium content of plants varies on its soil because it originates in soil and is variable. As a result, it is reasonable to expect that different radon emanation rates of wood should be detected by their regions. The radon measurements of wood are needed to examine according to wood species and producing countries. Therefore, this research aims to determine the basic data of the indoor radon exhalation rates from 4 native Korean species and one imported species of wood commonly used in Korean architecture for the characteristics of emanation according to wood species and producing countries (area), so that people utilized them as basic data for relevant research.

\section{MATERIALS and METHODS}

\subsection{Materials}

Five different air-dried wood species that were commonly used in Korean housing materials were used (2 kg each), 4 domestic and 1 imported. The domestic conifers used were: red pine (Pinus densiflora Siebold. \& Zucc.), Japanese larch (Larix kaempferi (Lamb.) Carriere), hinoki cypress (Chamaecyparis obtusa (Siebold. \& Zucc.) Endl), and sawtooth oak (Quercus accutissima Carruth). The imported species used were: northern red oak (Quercus rubra L. (imported wood)). The density, moisture content, and surface area of each wood specimen are listed in Table 1. A gypsum board made in the 2000s were also tested.

Table 1. Moisture content and density of wood species

\begin{tabular}{|c|c|c|c|c|}
\hline & Wood Species & $\begin{array}{c}\text { Density }\left(\mathrm{g} / \mathrm{cm}^{3}\right) \\
(\text { mean } \pm \mathrm{SD}) \\
\end{array}$ & $\begin{array}{l}\text { Moisture Content (\%) } \\
(\text { mean } \pm \text { SD) }\end{array}$ & Surface Area $\left(\mathrm{m}^{2}\right)$ \\
\hline \multirow{3}{*}{ Soft Wood } & $\begin{array}{l}\text { Pinus densiflora Siebold. } \\
\text { \& Zucc. }\end{array}$ & $0.46 \pm 0.027$ & $7.04 \pm 0.012$ & 0.245322 \\
\hline & $\begin{array}{c}\text { Larix kaempferi (Lamb.) } \\
\text { Carriere. }\end{array}$ & $0.57 \pm 0.022$ & $9.19 \pm 0.174$ & 0.233442 \\
\hline & $\begin{array}{l}\text { Chamaecyparis obtusa } \\
\text { (Siebold. \& Zucc.) Endl. }\end{array}$ & $0.43 \pm 0.023$ & $9.36 \pm 0.265$ & 0.245322 \\
\hline \multirow{2}{*}{ Hard Wood } & Quercus accutissima Carruth. & $0.76 \pm 0.066$ & $8.21 \pm 0.472$ & 0.218948 \\
\hline & Quercus rubra L. & $0.69 \pm 0.006$ & $7.80 \pm 0.022$ & 0.214434 \\
\hline
\end{tabular}




\subsection{Experiments}

Radon exhalations of each of the wood species were measured using the Closed Chamber Method (CCM) (Petropoulos et al., 2001) along with the Accumulator Method (AM). The self-designed acrylic hermetic chamber (Volume $=0.054 \mathrm{~m}^{2}$, I.D. $300 \mathrm{~mm} \times 300 \mathrm{~mm}$ x 600 mm: width $\mathrm{x}$ length $\mathrm{x}$ height) was specially constructed for this measurement. The Continuous Radon Monitor (CRM), Model 1028 (Sun Nuclear Corporation, USA, Dimensions $=236 \mathrm{~mm} \times 122 \mathrm{~mm}$ $x 74 \mathrm{~mm}$ ), was placed at the bottom of the chamber while an air-dried sample (2 kg) was placed $30 \mathrm{~cm}$ above the CRM as shown in Fig. 1. The specimens were made by $297 \mathrm{~mm}(w) \times 297 \mathrm{~mm}(l)$, and the heights were variable from 31 to $58 \mathrm{~mm}(h)$ because each sample had different density corresponding to its height. The detector was set to have 24 hours of delay time, and the samples were measured total of 12 times

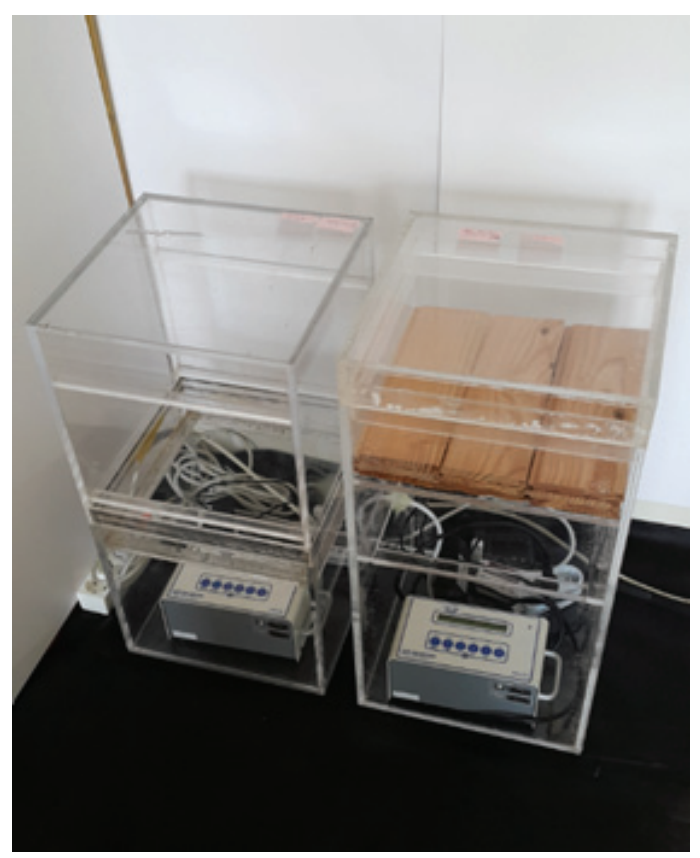

Fig. 1. Experiment set-up photograph for the closed chamber method. every two hours a day for 12 days since the preliminary experimental results had ensured to reach a constant level within 12 days. Lastly, the chamber was hermetically sealed. The temperature and humidity of the chamber were $25 \pm 2{ }^{\circ} \mathrm{C}$ and $\mathrm{RH} 50 \pm 10 \%$. Experiments were reflected in conditions representative of the humidity and temperature inside the average home in Korea. Additionally, one more chamber, which did not contain any samples, was located right next to the one with a sample so that radon exhalations not derived from the wood sample can be measured as the blank. Five wood samples and a gypsum board were tested by this method.

\subsection{Calculations}

Radon exhalation conversion from the measured concentration values were calculated as detailed below. First equation is of Petropoulos (2001), and it led directly to the second equation by Chen (2010), the third equation is Awhida (2016) combined the concept of measurement time, and the fourth equations have correction terms accounting for each background noise, mass and areal exhalation rate.

$$
\begin{gathered}
\mathrm{C}=\mathrm{Co} \cdot e^{-\lambda t}+E\left(1-e^{-\lambda t}\right)(\lambda V)^{-1} \\
\mathrm{C}=\mathrm{E} \cdot \mathrm{A}\left(1-e^{-\lambda t}\right)(\lambda V)^{-1}+C o \cdot e^{-\lambda t} \\
\mathrm{C}(\mathrm{t})=\mathrm{E} \cdot \mathrm{A}\left(1-e^{-\lambda t}\right)(\lambda V)^{-1} \ldots . . \\
E_{A}=\mathrm{C} \lambda V\left[A\left(1-e^{-\lambda t}\right)\right]^{-1} \ldots \ldots . . \\
E_{M}=\mathrm{C} \lambda V\left[M\left(1-e^{-\lambda t}\right)\right]^{-1}
\end{gathered}
$$

where

$$
\begin{aligned}
\mathrm{C}= & \text { the radon concentration }\left(\mathrm{Bqm}^{-3}\right) \text { in the } \\
& \text { container at growth timet }(\mathrm{h}) \\
\mathrm{E}= & \text { radon exhalation rate }\left(\mathrm{Bqh}^{-1}\right) \\
\mathrm{E}_{\mathrm{M}}= & \text { mass exhalation rate }(\mathrm{Bq} / \mathrm{kg} \cdot \mathrm{h}) \\
\mathrm{E}_{\mathrm{A}=}= & \text { areal exhalation rate }\left(\mathrm{Bq} / \mathrm{m}^{2} \mathrm{~h}\right) \\
\mathrm{V}= & \text { enclosing volume of the chamber }\left(\mathrm{m}^{3}\right)
\end{aligned}
$$


$\lambda=$ radon decay constant $\left(\mathrm{h}^{-1}\right)$

$\mathrm{t}=$ measurement time

Co $=$ the background radon concentration in the laboratory

A $=$ surface area of sample $\left(\mathrm{m}^{2}\right)$

$\mathrm{M}=$ mass of sample $(\mathrm{kg})$

\subsection{Radon exhalation rate analysis}

These results are presented from the measured values of wood as a building material by the equipment (CRM), Model 1028, to identify the characteristics of radon concentration. The analyses were processed by recorded concentration data, curves of measurement results, and U.S. Environmental Protection Agency (EPA) average. The statistical analyses [ANOVA, POST-HOC= SCHEFFE ALPHA (0.05)] were performed using IBM SPSS version 22 to determine the properties of wood species over the half-life with measured concentration of 138 radon counts, because the tendency was unknown only with the curves of the measured data.

\section{RESULTS and DISCUSSION}

\subsection{Radon exhalation rate}

As shown in Table 2, the concentrations of exhalation of all the tested wood species were measured to be distributed across an extremely low range of $0.1-0.2$ $\mathrm{pCi} / \mathrm{L}\left(3.7-7.4 \mathrm{~Bq} \cdot \mathrm{m}^{-3}\right)$ in chamber. The mass exhalation rates of all the species also ranged from only 0.00089 to $0.00181 \mathrm{~Bq} \cdot \mathrm{kg}^{-1} \cdot \mathrm{h}^{-1}$. Moreover, the surface exhalation rates resulted in $0.00677-0.01517 \mathrm{~Bq} \cdot \mathrm{m}^{2} \cdot \mathrm{h}^{-1}$ range. The average values were corrected by the blanks. There was no striking difference when comparing the averages between coniferous trees and deciduous trees in Table 2. Statistical significance test for group difference between not only softwoods and hardwoods but between wood species could not be determined. Although the detection concentration was seemingly too low, the statistical analysis was still worthwhile because the analysis was useful to confirm any difference of the half-lives, not only difference of tree species.

Based on the findings obtained, one can evaluate the contribution of the radon emanating from the wood materials used in a wooden house to its indoor radon levels. As a wooden house made of 100 percent of wood, for example, we assumed a a $162 \mathrm{~m}^{2}$ (width $\mathrm{x}$ length $=12 \mathrm{x} 13.5), 2.4 \mathrm{~m}$ high wooden ceiling, wood-frame structure with wooden floors and wooden wall panels, and an air-exchange rate in the range of 0.5 - 1 air changes per hour (ach). Depended on an average exhalation rate of $0.015 \mathrm{~Bq} \cdot \mathrm{m}^{-2} \cdot \mathrm{h}^{-1}$ (see Table

Table 2. Radon Concentration, surface exhalation rate and mass exhalation rate for wood species

\begin{tabular}{cccccc}
\hline Wood species & $\begin{array}{c}\text { EPA Avg. } \\
\text { in chamber } \\
(\mathrm{pCi} / \mathrm{l})\end{array}$ & $\begin{array}{c}\text { Vacant chamber } \\
(\mathrm{pCi} / \mathrm{l})\end{array}$ & $\begin{array}{c}\text { Concentration } \\
\text { of emanation } \\
(\mathrm{pCi} / \mathrm{l})\end{array}$ & $\begin{array}{c}\text { Surface exhalation } \\
\text { rate } \\
\left(\mathrm{Bq} \cdot \mathrm{m}^{-2} \cdot \mathrm{h}^{-1}\right)\end{array}$ & $\begin{array}{c}\text { Mass } \\
\text { exhalation rate } \\
\left(\mathrm{Bq} \cdot \mathrm{kg}^{-1} \cdot \mathrm{h}^{-1}\right)\end{array}$ \\
\hline \hline $\begin{array}{c}\text { Pinus densiflora } \\
\text { Siebold. \& Zucc. }\end{array}$ & 0.3 & 0.2 & 0.1 & 0.00677 & 0.00089 \\
$\begin{array}{c}\text { Larix kaempferi } \\
\text { (Lamb.) Carriere. }\end{array}$ & 0.3 & 0.2 & 0.1 & 0.00711 & 0.00091 \\
$\begin{array}{c}\text { Chamaecyparis } \\
\text { obtusa (Siebold. } \\
\text { \& Zucc.) Endl. }\end{array}$ & 0.5 & 0.4 & 0.1 & 0.00677 & 0.00092 \\
$\begin{array}{c}\text { Quercus } \\
\text { accutissima } \\
\text { Carruth. }\end{array}$ & 0.6 & 0.4 & 0.2 & 0.01517 & 0.00181 \\
Quercus rubra L. & 0.5 & 0.4 & 0.1 & 0.00774 & 0.00090 \\
\hline
\end{tabular}


2 ), which was the highest outcome among the five species, the contribution of the wood material to indoor radon concentration would be on the order of about $0.017-0.034 \mathrm{~Bq} \cdot \mathrm{m}^{-3}$. It is significantly by less than concentrations of $37.0 \mathrm{~Bq} \cdot \mathrm{m}^{-3}$ which observed in structures built from wood materials (KINS 2002). Even for air exchange rates of 0.1 ach, the resulting concentration was calculated as $0.172 \mathrm{~Bq} \cdot \mathrm{m}^{-3}$, which is far below the Korean radon recommendation level, $200 \mathrm{~Bq} \cdot \mathrm{m}^{-3}$ (Ministry of Environment, 2016). On the other hand, to compare our results of the radon exhalation rate from wood materials with those of other construction materials from variable references in Table 3 , wood belonged to the lowest group of the radon

Table 3. Radon exhalation rates of building materials from various references

\begin{tabular}{|c|c|c|c|c|}
\hline Material & $\begin{array}{l}\text { Radon exhalation } \\
\text { per unit area } \\
\left(\mathrm{Bq} / \mathrm{m}^{2} \cdot \mathrm{h}\right)\end{array}$ & $\begin{array}{l}\text { Radon exhalation } \\
\text { per unit weight } \\
(\mathrm{Bq} / \mathrm{kg} \cdot \mathrm{h})\end{array}$ & Origin & Researcher \\
\hline Concrete & 0.34314 & 0.00378 & \multirow{11}{*}{ S. Korea } & \multirow{11}{*}{$\begin{array}{l}\text { Lee, et al. } \\
\text { March } 2015\end{array}$} \\
\hline Cement Mortar & 0.10749 & 0.00217 & & \\
\hline Block & 0.45641 & 0.00603 & & \\
\hline Brick-General & 0.60028 & 0.00733 & & \\
\hline Lightweight Foam Panel(ALC) & 0.08682 & 0.00515 & & \\
\hline Sand & 0.18521 & 0.00433 & & \\
\hline Granite & 0.06119 & 0.00055 & & \\
\hline Gypsum Cement Fiber Board & 0.47708 & 0.05885 & & \\
\hline Ceramic Tile & 0.00413 & 0.00061 & & \\
\hline Phosphogypsum Board & 0.01158 & 0.00185 & & \\
\hline Glass Wool & 0.01488 & 0.00579 & & \\
\hline $\begin{array}{l}\text { Gypsum board } \\
\text { Marble } \\
\text { Tile }\end{array}$ & $\begin{array}{l}0.04051 \\
0.01075 \\
0.00413\end{array}$ & - & S. Korea & $\begin{array}{l}\text { Lee, et al. } \\
\text { Sep. } 2015\end{array}$ \\
\hline Bricks & 0.212 & \multirow{4}{*}{ - } & \multirow{4}{*}{ Pakistan } & \multirow{4}{*}{$\begin{array}{l}\text { Faheem, et al, } \\
2008\end{array}$} \\
\hline Cement & 0.231 & & & \\
\hline Marble & 0.120 & & & \\
\hline Sand & 0.292 & & & \\
\hline Cement & 1.24 & 0.35 & Iraq & \multirow{6}{*}{ Najam, et al. 2013} \\
\hline Bricks & 1.01 & 0.28 & Iraq & \\
\hline Block & 1.52 & 0.43 & Iraq & \\
\hline Black marble & 1.26 & 0.36 & Turkish & \\
\hline Green Ceramics & 1.31 & 0.37 & Turkish & \\
\hline Red granite & 2.30 & 0.65 & Turkish & \\
\hline Wood & $0.00677-0.01517$ & 0.00089-0.00181 & S. Korea & Present Study \\
\hline Material & $\begin{array}{l}\text { Radon exhalation } \\
\text { per unit area } \\
\left(\mathrm{nBq} / \mathrm{cm}^{2} \cdot \mathrm{s}\right)\end{array}$ & $\begin{array}{l}\text { Radon exhalation } \\
\text { per unit weight } \\
(\mathrm{Bq} / \mathrm{kg} \cdot \mathrm{h})\end{array}$ & Origin & Researcher \\
\hline Wood & - & $\begin{array}{c}0.00074 \\
(=0.02 \mathrm{pCi} / \mathrm{kg} \cdot \mathrm{h})\end{array}$ & U.S.A. & $\begin{array}{l}\text { Ingersoll, } \\
1983\end{array}$ \\
\hline Wood & $0.1-0.2$ & $\begin{aligned} & 0.00036-0.00072 \\
(= & \left.0.1-0.2 \mathrm{nBq} \cdot \mathrm{g}^{-1} \cdot \mathrm{s}^{-1}\right)\end{aligned}$ & Canada & Zikovsky, 1992 \\
\hline Material & $\begin{array}{l}\text { Radon exhalation } \\
\text { per unit area } \\
\left(\mathrm{Bq} / \mathrm{m}^{2} \cdot \mathrm{d}\right)\end{array}$ & $\begin{array}{c}\text { Radon exhalation } \\
\text { per unit weight } \\
(\mathrm{Bq} / \mathrm{kg} \cdot \mathrm{h})\end{array}$ & Origin & Researcher \\
\hline $\begin{array}{l}\text { Red Dragon -granite } \\
\text { Caladonia-granite }\end{array}$ & $\begin{array}{c}261 \pm 37(212-299) \\
0.4 \pm 0.4(0.2-1.0)\end{array}$ & - & $\begin{array}{c}\text { Brazil } \\
\text { Canada }\end{array}$ & Chen, et al. 2010 \\
\hline
\end{tabular}


exhalation among the various building materials. To have a better comparison, the extracts in Table 3 culled from the 5 different cited references. For example, although Lee et al. (2015) had identified radon exhalation rates for 10 framing materials and 16 finishing materials out of 26 total building materials used in the Korean construction industry, only 8 framing materials and 4 finishing materials were extracted for this trend analysis. The extracted radon exhalation values of the same object showed different figures because the values were derived from various countries and origins. Based on the results of Chen (2010), slate and granite generally had higher radon exhalation rates, which was varied widely from non-detectable to about $300 \mathrm{~Bq} \cdot \mathrm{m}^{-2} \cdot \mathrm{d}^{-1}$, than other decorative materials. The average radon exhalation rates were $30 \pm 16 \mathrm{~Bq} \cdot \mathrm{m}^{-2} \cdot \mathrm{d}^{-1}$ for slate and $42 \pm 63$ $\mathrm{Bq} \cdot \mathrm{m}^{-2} \mathrm{~d}^{-1}$ for granite, respectively.

Korea Institute of Nuclear Safety (KINS) in 2002 reported that wood materials yielded second highest radon concentration levels among other commonly used materials in Korean architecture. In 2010, KINS also reported a list of radon concentrations emitted by various common construction materials: wood $(37.0 \pm 21.9$ $\mathrm{Bq} / \mathrm{m}^{3}$ ), red brick $\left(27.9 \pm 7.2 \mathrm{~Bq} / \mathrm{m}^{3}\right)$, concrete (26.8 $\left.\pm 19.4 \mathrm{~Bq} / \mathrm{m}^{3}\right)$, cement block $\left(25.9 \pm 10.8 \mathrm{~Bq} / \mathrm{m}^{3}\right)$, stone $\left(24.7 \pm 11.1 \mathrm{~Bq} / \mathrm{m}^{3}\right)$; tested at the Nationwide Survey of Indoor Radon in Korea (2) - Public facilities. Wood was reported to have significantly high amount of radon concentration emission; however, the radon exhalation rate of wood itself proved the lowest group among those of the building materials from the present experiment. Also, Ingersoll (1983) reported the same results that wood was the weakest emanatory in building materials. He showed that the mean radon emanation rates of wood were $0.02 \mathrm{pCi} \cdot \mathrm{kg}^{-1} \cdot \mathrm{h}^{-1}$ for two wood samples of unknown species from the western states of the U.S.A. by the gamma-ray spectroscopy techniques. These rates were very similar to $0.1-0.2 \mathrm{nBq} \cdot \mathrm{g}^{-1} \cdot \mathrm{s}^{-1}$, proven by
Zikovsky (1992), for two wood samples of unknown species purchased from stores in the Montreal area by the method of internal proportional counter. The measured rates from wood used in the U.S.A. and Canada were very close to the present results as shown in Table 3. The radon exhalation rate of Quercus accutissima Carruth (white oak) which has the highest density showed the highest value among the five wood species, on the other hand, the rest of four species stayed at the very low levels. National Research Council (US) Committee (1999) noticed that Radium, chemically similar to calcium, is imbibed from the soil by plants. The radium content of plants varies on its soil because it originates in soil and is variable. As a result, it is reasonable to expect that different radon emanation rates of wood should be detected with variety of resources according to their regions. The present results confirmed that radon exhalation rate of wood itself considered the lowest group in building materials. The data from scientific reports mentioned above and the results from our experiment shows the potentially hazardous influx of radon exhalation from the surrounding of wood building, not the wood material itself. Therefore, preventions of influx of radon and selection of construction-finishing materials should be taken into consideration in architectural construction methods. Furthermore, it is highly desirable that wood will be required for furniture and even as interior finishing material in indoor environment.

\subsection{The results according to half-life of wood species.}

Stranden (1988) noted that Closed Chamber Method (CCM) is the most popular way to estimate the emanation rate of a building material. Radon concentration growth in the closed chamber reaches its peak and equilibrium conditions dependent on radon emanation through half-lives of several times. To 
compare with wood and gypsum board, which is commonly known as possessing high radon emanation, Fig. 3 shows that high radon concentration of gypsum board made in the 2000s, and it certainly shows what the tendency is about from the experimental result. As a result, equilibrium was preserved in $4^{\text {th }}$ half-life. In contrast, wood stayed at the low radon concentration, and there was no difference between half-lives as shown in Fig. 2 about Larix kaempferi (Lamb.) Carriere. In the Fig. 2 and 3, the results of radon concentrations for both materials in the chamber without reflecting its background effect are shown.

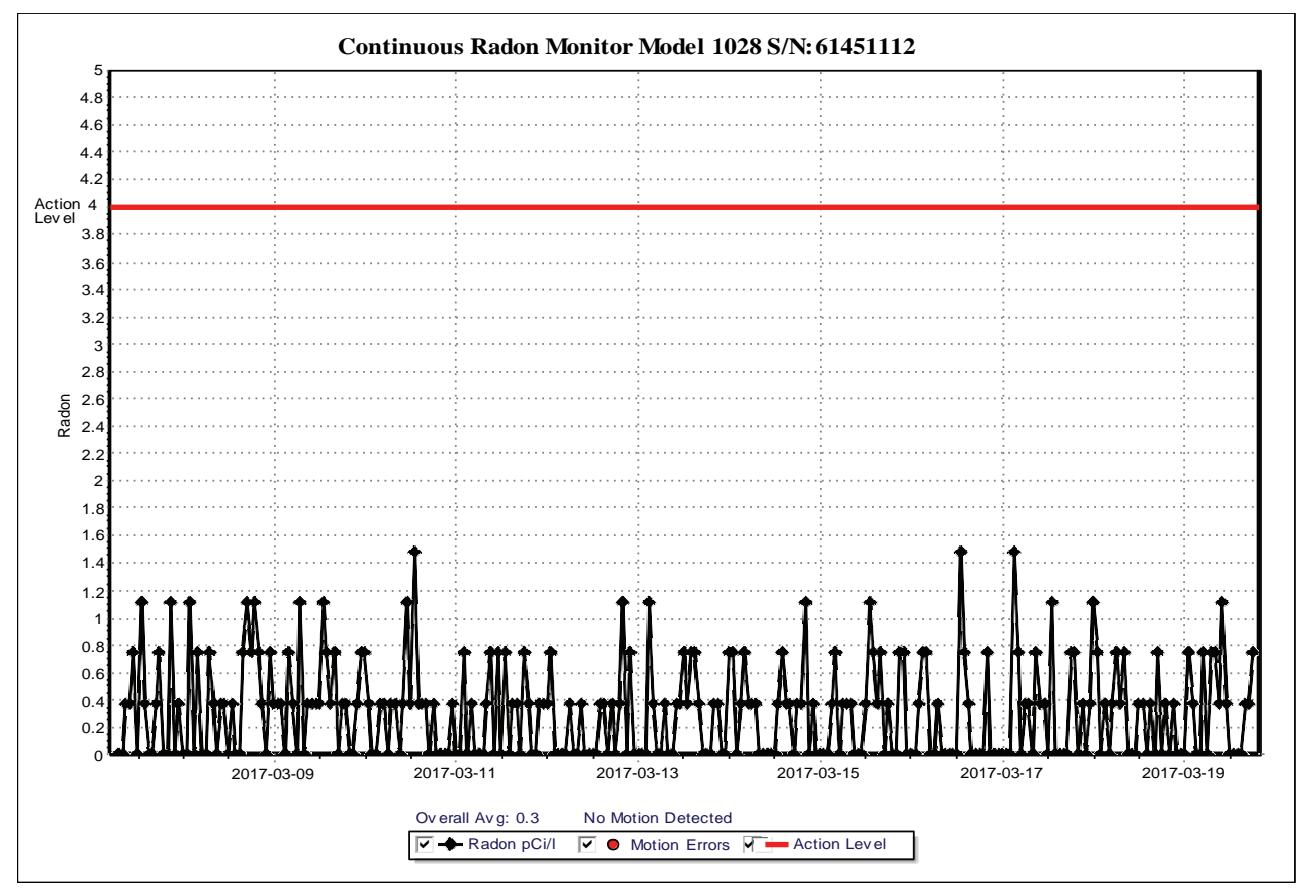

Day average of radon concentration from Larix kaempferi (Lamb.) Carriere. by multiple comparison.

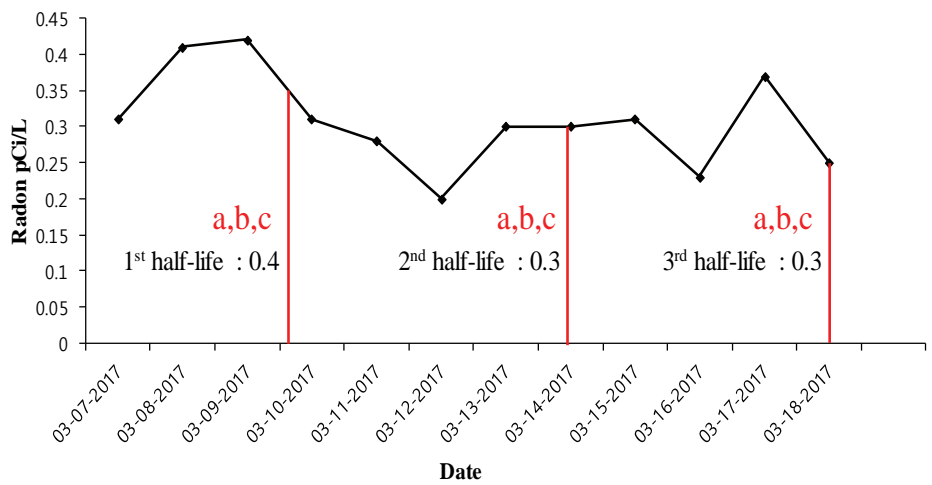

Fig. 2. Radon concentration of Larix kaempferi (Lamb.) Carriere. in chamber 

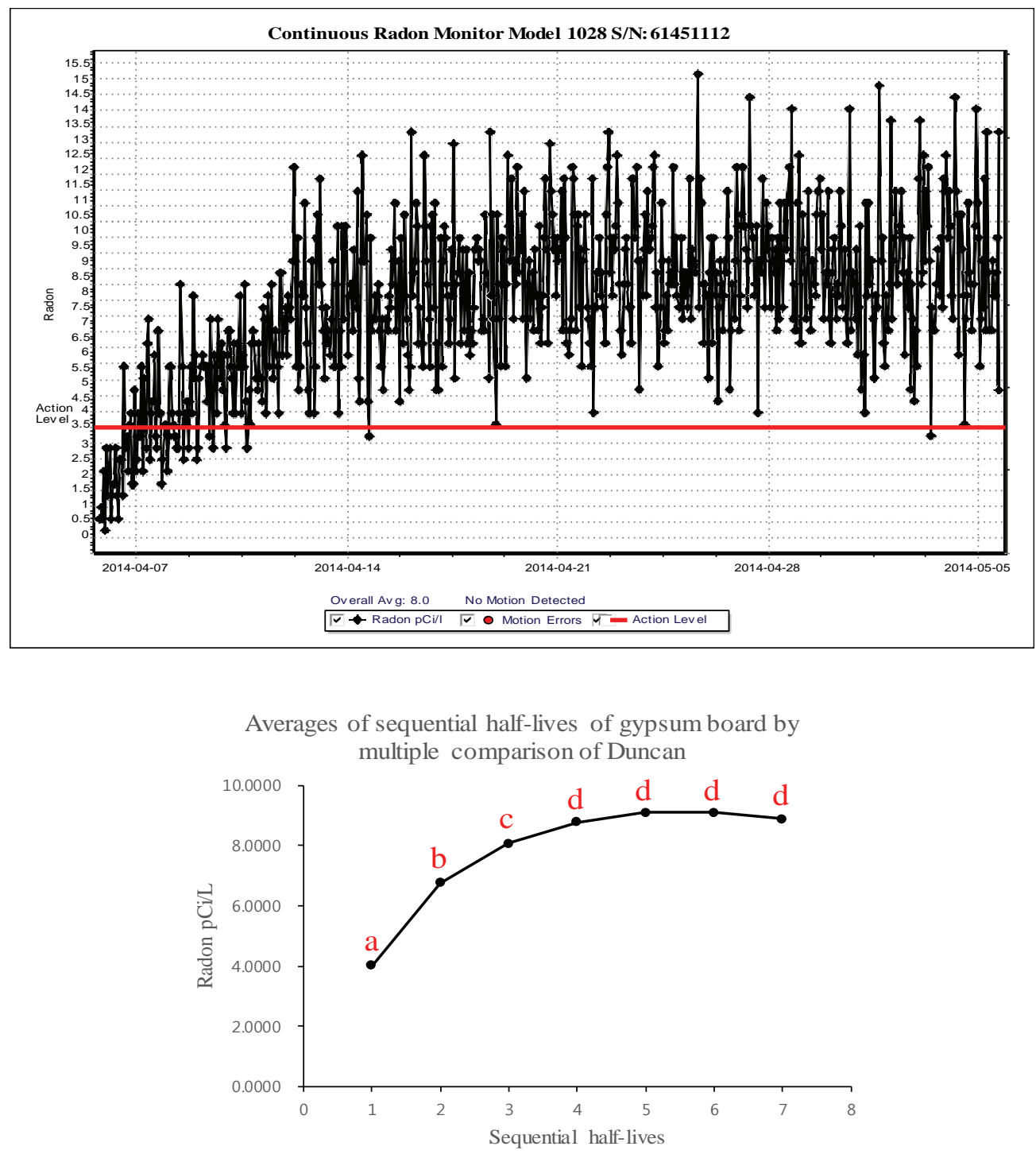

Fig. 3. Radon concentration of gypsum board in chamber.

Using CCM and accumulator method (AM) the radon concentrations of wood species were compared with up to the $3^{\text {rd }}$ half-life. More measurements were not taken since the average peaks of the concentrations were reached at the $2^{\text {nd }}$ half-life, as shown in Table 4 . The measurements of the concentration were taken only 8 days, unlike other reports previously mentioned (Lee et al., 2015 ; Najam et al., 2013) that took 2 to 3 months. When the EPA averages in Table 2 were calibrated by the average of correction value within the same species, the statistical significance test for group difference between half-lives indicated the same results because there were no big differences between the corrected average values and original non-corrected 
Table 4. Group differences among half-lives of radon exhalation from wood species

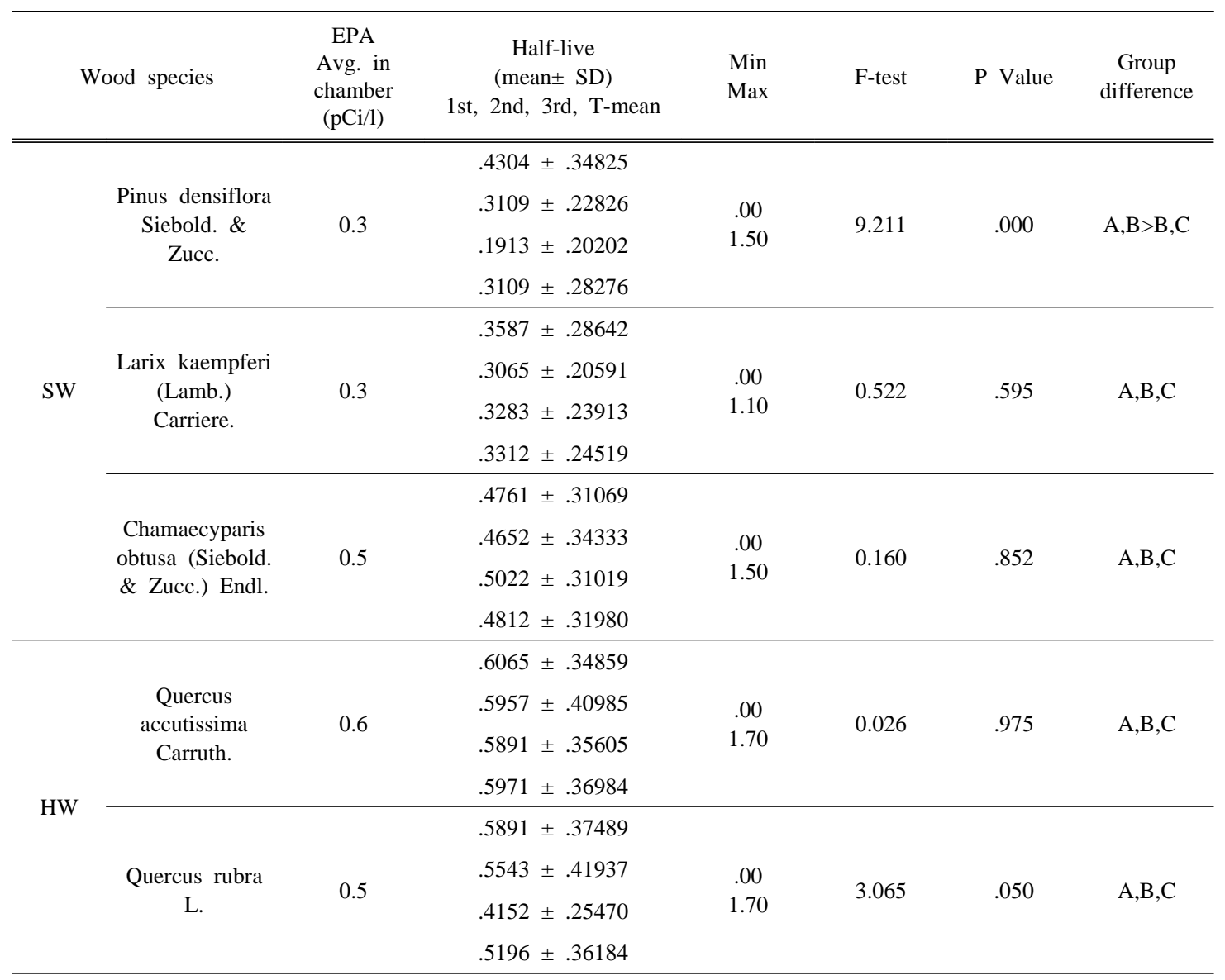

measured values. In addition, the reason why the correcting background effect was not performed is that each of the samples and background recorded differently at different times. The correcting values were not able to be proceeded every single count of sample and blank. Due to this difficulty, the average values were corrected by calibration.

As a result, statistical analysis was necessary because it is different, whether the maximum values are reached quickly or not, by the half-lives and the characteristics of the samples. The original measured values without the correction were used for group difference among half-lives. As a result of the statistical processing data, four species had the same results on the $1^{\text {st }}, 2^{\text {nd }}$, and $3^{\text {rd }}$ half-lives. Therefore, the measurement was enough until the $1^{\text {st }}$ half-life period, but only one species was measured up to the $2^{\text {nd }}$ half-life period although the experiment was proceeded until the $3^{\text {rd }}$ half-life period to compare between $2^{\text {nd }}$ and $3^{\text {rd }}$ half-lives.

\section{CONCLUSION}

The most widely used wood species in Korean residential architecture, 4 domestic Korean species of wood and 1 imported species, were selected to test their radon emissions. The purpose of this experiment 
was to present the basic data of the indoor radon pollution level by examining the radon exhalation rates of wood species. The measured results of radon concentrations were extremely small $(0.1-0.2 \mathrm{pCi} / \mathrm{L})$, along with the exhalation rates per unit weight that were also low, 0.00089-0.00181 $\mathrm{Bq} \cdot \mathrm{kg}^{-1} \cdot \mathrm{h}^{-1}$. The exhalation rates per unit of area showed 0.00677-0.01517 $\mathrm{Bq} \cdot \mathrm{m}^{2} \cdot \mathrm{h}^{-1}$. The radon exhalation rates of Quercus accutissima Carruth (white oak) with the highest density indicated the highest rate among the five wood species while the rest of four species recorded at the low rate levels. These were confirmed by the previous reported papers from the U.S.A. and Canada. The average radon concentration measured greatly showed up to the $2^{\text {nd }}$ half-life (7.7 days). These measurements of small quantities were concluded to have almost negligible impact from the wood itself. These results lead clearly to that it is a matter of the surrounding environment of building, not the matter of wood materials. Therefore, as a safety precaution, infrastructures made of wood materials in Korean wood house should be constructed with the consideration influx of radon and built accordingly. Furthermore, it is highly recommended that wood should be required to use for furniture and as interior finishing material in indoor environment.

\section{ACKNOWLEDGMENT}

This study was carried out with the support of 'R\&D Program for Forest Science Technology (Project No. 2017049A00-1819-BB02)' provided by Korea Forest Service(Korea Forestry Promotion Institute).

\section{REFERENCES}

Awhida, A., Ujic, P., Vukanac, I., Đurasevic, M., Kandic, A., Celikovic, I., Loncar, B., Kolarz, P. 2016. Novel method of measurement of radon exhalation from building materials. Journal of
Environmental Radioactivity 164: 337-343.

Chen, J., Rahman, N.M., Atiya, I.A. 2010. Radon exhalation from building materials for decorative use. Journal of Environmental Radioactivity 101(4): 317-322.

Cho, Y.M., Lee, H.H. 2011. Effect of black charcoal and activated carbon for reduction of radon radioactivity that emitted from building materials. Journal of Korea Furniture Society 22(1): 13-17.

Jang, J.H., Lee, M., Lee, S.M., Park, S.B. 2017. Formaldehyde Emission of Building Materials and Effect of Carbonized Board on Their Reduction. Journal of Korean Wood Science and Technology 45(3): 327-334.

European Communities (EC). 1999. Radiological protection principles concerning the natural radioactivity of building materials, 112, Radiation Protection.

Faheem, Munazza., and Matiullah. 2008. Radon exhalation and its dependence on moisture content from samples of soil and building materials. Radiation Measurements 43: 1458 - 1462.

Fleischer, R.L., Mogro-Campero, A. 1978. Mapping of integrated radon emanation for detection of long-distance migration of gases within the Earth: Techniques and principles. Journal of Geophysical Research. Solid Earth 83(B7): 3539-3549.

Gibson, G.J., Loddenkemper, R., Sibille, Y., Lundback, B. 2013. The European Lung White Book: Respiratory Health and Disease in Europe (2nd ed). European Respiratory Society, Sheffield.

Ingersoll, J.G. 1983. A survey of radionuclide contents and radon emanation rates in building materials used in the U.S. Health Physics 45(2): 363-368. Jang, M., Kang, C.S., Moon, J.H. 2004. Estimation of 222Rn release from the phosphogypsum board used in housing panels. Journal of Environmental Radioactivity 80: 153-160.

Jing, C., Navreen, M.R., Ibrahim, A.A. 2010. Radon 
exhalation from building materials for the decorative use. Journal of Environment Radioactivity 101: 317-322.

Khan, A.J., Prasad, R., Tyagi, R.K, 1992. Measurement of radon exhalation rate from some building materials. International Journal of Radiation Applications \& Instrumentation. Part D, Nuclear Tracks \& Radiation Measurements 20(4): 609-610.

Korea Institute of Nuclear Safety. 2002. Assessment of Radiation Risk for Korean Population and Nationwide Indoor Radon Survey in Korea; Nationwide Survey of Indoor Radon Level in Korea. KINS/Gr 246 Final Report. Kim, C. K., et al.

Korean Ministry of Environment. 2016. Enforcement Decree of Indoor Air Quality Control in Public Use Facilities, ETC. ACT. 2017. 6. 28. Implement, Promulgation No. 28158. Promulgation Date 2017.06.27.

Lázár, I., Tóth, E., Marx, G., Cziegler, I., Kötdes, G. J. 2003. Effects of residential radon on cancer incidence. Journal of Radioanalytical and Nuclear Chemistry 258(3): 519-524.

Lubin, J.H., Boice Jr., J.D. 1997. Lung cancer risk from residential radon: meta-analysis of eight epidemiologic studies. Journal of the National Cancer Institute 89(1): 49-56.

Lee, C.M., J, S.W., Lee, D.H., Kim, Y.B., Lee, D.J., Cho, Y.S., Jin, Y.H. 2015. Investigation of radon emanation of domestic building materials. Journal of Odor and Indoor Environment 14(1): 57.

Lee, C.M., Gwak, Y.K., Lee, D H., Lee, D.J., Cho, Y.S. 2015. A study on the prediction of indoor concentration due to radon exhalation from domestic building materials. Journal of Environmental Science International. 24(9): 1131-1138.

Lee, J.Y, Lee, H.C., Han, K.M., Kim, N.J., Jeon, J.S., Kim, J.H., Kim, M.Y. 2007. Source and variations of radon-222 concentrations in indoor air. Report of The Swedish Centre for Studies of the
Internationalisation of Higher Education 43: 355360 .

Lee, M., Park, S.B., Lee, S.M., Son. D.W. 2014. Radon emission from construction materials and reduction effect of carbonized boards. Proceedings of the Korean Wood Science and Technology pp. 68-69.

Mahur, A.K., Kumar, R., Sengupta, D., Prasad, R. 2008a. Estimation of radon exhalation rate, natural radioacivity and radiation doses in fly ash samples from Durgapur thermal power plant, West Bengal, India. Journal of Environmental Radioactivity 99(8): 1289-1293.

Mahur, A.K., Kumar, R., Sengupta, D., Prasad, R. 2008b. An investigation of radon exhalation rate and estimation of radiation doses in coal and fly ash samples. Applied Radiation and Isotopes 66(3): 401-406.

Laith A. Najam, Nada F. Tawfiq, Rana Hesham Mahmood. 2013. Radon Concentration in Some Building Materials in Iraq Using CR-39 Track Detector. International Journal of Physics 1(3): 73-76.

National Institute of Environmental Research. 2010. Nationwide Survey of Indoor Radon in Korea ( II ) - Public facilities. Final Report.

National Research Council (US). 1999. Evaluation of Guidelines for Exposures to Technologically Enhanced Naturally Occurring Radioactive Materials. Washington (DC): National Academies Press (US).

Neuberger, J.S., Gesell, T.F. 2002. Residential radon exposure and lung cancer: risk in nonsmokers. Health Physics 83(1): 1-18.

Petropoulos, N.P., Anagnostakis, M.J., Simopoulos, S.E. 2001. Building materials radon exhalation rate: ERRICCA intercomparison exercise results. Science of the Total Environment 272: 109-118.

Saad, A. F., Abdalla, Y.K., Hussein, N.A., Elyaseery, I.S. 2010. Radon exhalation rate from building materials used on the Garyounis University campus, 
Benghazi, Libya, Turkish. Journal of Engineering and Environmental Sciences 34: 67-74.

Saad, A.F., Abdallah, R.M., Hussein, N.A. 2013. Radon exhalation from Libyan soil samples measured with the SSNTD technique. Applied Radiation and Isotopes 72: 163-168.

Singh, A.K., Kumar, A., Prasad, R. 2006. Distribution of radon levels in Udaipur. Asian Journal of Chemistry 18(5): 3408-3411.

Stranden, E. 1988. Building materials as a source of indoor radon. In Nazarof, W. W., and Nero Jr., A. V., (Eds) Radon and its decay products in indoor air, John Wiley \& Sons, Inc.: New York pp. 113-
130.

Webb, G.A.M. 1992. Exposure to Radon. Radiation Protection Dosimetry 42(3): 191-195.

WHO Handbook on Indoor Radon: A Public Health Perspective. Geneva: World Health Organization; 2009.

Zikovsky, L. 1992. Determination of radon exhalation rates from Canadian building materials with an internal proportional counter. International Journal of Radiation Applications and Instrumentation, Part D. Nuclear Tracks and Radiation Measurements 20(3): 525-521. 